\title{
Pattern of clinically recognisable congenital malformations in babies born in a tertiary referral centre in Sri Lanka
}

\author{
S Fernando ${ }^{1}$, T Bandara ${ }^{2}$, R Sathanantharajah ${ }^{1}$, K Withanaarachchi $^{1}$ \\ (Index words: congenital malformations, aetiology, incidence, live newborns, risk factors)
}

\begin{abstract}
Objectives To record incidence, pattern and prevalence of risk factors of congenital malformations (CM) in live new born babies at a Teaching Hospital in Sri Lanka.

Methods All newborn babies delivered over a period of six months at the Teaching Hospital, Mahamodara were included in this cross sectional study and they were subjected to thorough medical examination to detect any CM. An interviewer administered questionnaire was used to collect information on socio-demographics and risk factors associated with $\mathrm{CM}$.

Results Overall prevalence of $\mathrm{CM}$ in the study group was $4.3 \%$. Occurrence was higher in males $(61.4 \%)$ than females $(36.9 \%)$. Highest frequency of CM was in the musculoskeletal system. Parents' age, previous history of abortions or stillbirths, consanguinity and pre-conceptual folic acid deficiency were the most prevalent risk factors related to $\mathrm{CM}$.

Conclusions Prevalence of CM in the study group is high compared to other countries in the region. Emphasis on preventing $\mathrm{CM}$ is recommended and public health actions is required in improving well-being of affected babies.
\end{abstract}

Ceylon Medical Journal 2014; 59: 132-135

\section{Introduction}

Congenital malformations are defined as structural defects, chromosomal abnormalities, inborn errors of metabolism and hereditary diseases diagnosed before, at, or after birth [1]. About 2-3\% of births are associated with major CM, which are diagnosed at or soon after birth. In 1997 about 495,000 deaths were reported worldwide due to congenital anomalies [1]. CM is one of the leading causes of miscarriage. It also contributes significantly to preterm births and childhood and adult morbidity [2]. The main causes of infant morbidity and mortality in the poorer countries are infections and malnutrition, whereas in the developed countries the causes include cancer, accidents and CM [3-5]. Treatment and rehabilitation of children with congenital anomalies is costly and usually complete recovery is not possible [6]. Since 1960s a general sur-veillance has been carried out monitoring congenital anomalies in different populations across the globe [7]. According to worldwide surveys the prevalence of congenital malformations varies greatly from country to country [8]. Such variations could be explained by social, racial, ecological and economical differences $[9,10]$.

$\mathrm{CM}$ can present either as a primary defect in development or as a multiple malformation syndrome. Approximately $66 \%$ of major malformations have no recognised aetiology. Most of them are of multi-factorial inheritance [11-13]. Genetic factors (multi-factorial, single gene or chromosomal), environmental factors, teratogenic agents, infections, medical problems, chemical agents, drugs and radiation are among the most common aetiological factors for congenital malformations. Some maternal conditions such as alcoholism, diabetes, endocrinopathies and nutritional deficiencies are also important [14].

Identification of the distribution and aetiology of $\mathrm{CM}$ is important to reduce its incidence and prevalence. The objectives were to estimate the rate and sex ratio of $\mathrm{CM}$, identify types of CM and aetiological factors in new born babies born at a teaching hospital over a period of six months.

\section{Methods}

This was a prospective study. The study was conducted at the Teaching Hospital, Mahamodara, Galle, Sri Lanka, which serves as the major referral centre for obstetrics and gynaecology and prenatal intensive care in the Southern Province of Sri Lanka. All new born babies delivered at the hospital over a period of six months from 1st January 2012 were enrolled in the study.

Approval was obtained from the Ethics Review Committee, Faculty of Medicine, University of Ruhuna, Sri Lanka. Institutional approval was obtained from the hospital. Written informed consent was obtained from mothers of the babies. All babies born during the above

${ }^{1}$ Teaching Hospital, Mahamodara and ${ }^{2}$ Faculty of Medicine, University of Ruhuna, Sri Lanka.

Correspondence: TB, e-mail: <wvthush@yahoo.com>. Received 16 May 2014 and revised version accepted 6 October 2014. Competing interests: none declared. 
mentioned period were examined by medical officers and the occurrence of CM were confirmed by the consultant paediatrician or consultant neonatologist. Information of the babies with CM and their mothers' were gathered using a questionnaire. Questionnaire was filled by pediatricians and medical officers after examining the babies and interviewing their mothers. The questionnaire included information about the baby, mother and family such as date of birth, demographic data, nationality, consanguinity, maternal age, socioeconomic status, medical information, birth status, plurality, previous history of abortions, previous children with congenital anomalies, sex, weight, diagnostic methods and diagnosis. Hospital records, diagnosis cards and reports of investigations were also examined.

Data were computed and analysed using Statistical Package for Social Sciences (SPSS) software, version 20 (Chicago, USA). Types of birth defects were classified. Means and percentages were calculated. The rates of prevailing risk factors were compared using non parametric tests (chi-squared tests). $P<0.05$ was considered as statistically significant.

\section{Results}

During the six month study period, there were 5788 deliveries, of them 5746 were live births. Congenital malformations were detected in 249 babies (4.3\%). About $146(58.6 \%)$ were delivered by natural vaginal delivery and $103(41.3 \%)$ by a casesarean section. Table 1 presents the different types of Congenital malformations.Feet deformities, hip deformities, haemangioma, preauricular skin tag, preauricular sinus and hypopigmented patches were the major abnormalities of the musculoskeletal system. Tongue tie was the major deformity of the digestive system (61 cases). The commonest anomalies in the genital and urinary systems were undescended testes, hypospiadiasis and hydrocele. Atrial septal defect (ASD), ventricular septal defect (VSD), patent ductus arteriosus (PDA) and left to right shunt were the commonest abnormalities of the circulatory system. Anencephaly, myelomeningocele, hydrocephalus and sacral pit were the major neurological deformities. Down's syndrome was the commonest chromosomal abnormality.CM according to the system affected are presented in table 2 .

The incidence of the CM was significantly higher in males $(p<0.001)$. There were $153(61.4 \%)$ males, 92 $(36.9 \%)$ females and $4(1.6 \%)$ with ambiguous genitalia. The male to female sex ratio was 1.6:1. Distribution of the $\mathrm{CM}$ according to maternal characteristic is presented in table 3 . High rates of $\mathrm{CM}$ were seen in babies born to mothers aged $>30$ years, babies born after 37-40 weeks gestation and in the $\mathrm{O}$ positive blood group. Parity was 1 in $41.2 \%$ of the reported cases. Ethnic distribution of mother were Sinhalese $91.2 \%$, Muslim $68 \%$ and Tamil $2 \%$.
Consanguinity in parents was reported in $4.4 \%$. Only $38 \%$ of mothers who gave births to babies with CM had consumed folic acid before conceiving. However, 96\% mothers consumed folic acid during the antenatal period.

Table 1. Nature of the congenital malformations

\begin{tabular}{|c|c|}
\hline Abnormality & Number \\
\hline \multicolumn{2}{|l|}{ Neurological system } \\
\hline Anencephaly & 4 \\
\hline Microcephaly & 1 \\
\hline Congenital Hydrocephalus & 3 \\
\hline Myelomeningocele & 4 \\
\hline $\begin{array}{l}\text { Others (Hydrocephalus, Sacral pit, } \\
\text { Encephalocele) }\end{array}$ & 9 \\
\hline Eye /ear / neck & 2 \\
\hline \multicolumn{2}{|l|}{ Circulatory system } \\
\hline High risk heart diseases & 4 \\
\hline Intermediate risk heart diseases & 1 \\
\hline Low risk heart diseases & 22 \\
\hline \multicolumn{2}{|l|}{ Cleft lip and palate } \\
\hline Cleft lip & 2 \\
\hline Cleft palate & 1 \\
\hline Cleft lip and palate & 4 \\
\hline \multicolumn{2}{|l|}{ Digestive system } \\
\hline Duodenal atrisia & 2 \\
\hline Tongue tie & 61 \\
\hline Tracheo-oesophageal fistula & 1 \\
\hline Others (anterior place anus, absent anus etc) & 4 \\
\hline \multicolumn{2}{|l|}{ Genital and urinary system } \\
\hline Undescended testes & 21 \\
\hline Hypospidiasis & 11 \\
\hline Ambiguous genitalia & 2 \\
\hline Hydrocele & 7 \\
\hline Others & 7 \\
\hline \multicolumn{2}{|l|}{ Musculo-skeletal system } \\
\hline Hip deformities & 7 \\
\hline Feet deformities & 10 \\
\hline Polydactyly and syndactyly & 6 \\
\hline Diaphramatic hernia & 5 \\
\hline Haemangioma & 9 \\
\hline Preauricular skin tag & 9 \\
\hline Hypopigmented patches & 9 \\
\hline Preauricular sinus & 6 \\
\hline Others & 21 \\
\hline \multicolumn{2}{|l|}{ Chromosomal abnormalities } \\
\hline Down's syndrome & 6 \\
\hline Dandrywark syndrome & 1 \\
\hline Edward's and Patau's syndrome & 1 \\
\hline Total & 263 \\
\hline
\end{tabular}

Table 2. Distribution of congenital malformations according to systems

\begin{tabular}{lcc}
\hline \multicolumn{1}{c}{ System } & Number & Percentage \\
\hline Neurological & 21 & 8.0 \\
Eye, ear and neck & 02 & 0.8 \\
Circulatory & 27 & 10.3 \\
Digestive & 75 & 28.5 \\
Genital and urinary & 48 & 18.3 \\
Musculoskeletal & 82 & 31.2 \\
Multiple system syndrome & 08 & 3.0 \\
Total & $\mathbf{2 6 3}$ & $\mathbf{1 0 0 . 0}$ \\
\hline
\end{tabular}


Twenty two $(9.05 \%)$ mothers had a history of medical illnesses. Six (2.4\%) had diabetes mellitus and were treated with insulin. Six mothers $(2.4 \%)$ had taken salbutamol for asthma and the rest had been on nifedipine, amoxycillin or warfarin during pregnancy. None of the mothers had epilepsy or infective diseases such as toxoplasmosis, rubella, cytomegalovirus or herpes.

Table 3. Characteristics of the mother

\begin{tabular}{|c|c|c|}
\hline Characteristic & Number & Percentage \\
\hline \multicolumn{3}{|l|}{ Age (years) $(n=240)$} \\
\hline $\begin{array}{l}\leq 25 \\
26-30 \\
>30\end{array}$ & $\begin{array}{c}64 \\
75 \\
101\end{array}$ & $\begin{array}{l}26.7 \\
31.2 \\
42.1 *\end{array}$ \\
\hline $\begin{array}{l}\text { Gestational age in weeks }(n= \\
\leq 36 \\
37-40 \\
>41\end{array}$ & $\begin{array}{r}39 \\
30 \\
175\end{array}$ & $\begin{array}{l}16.0 \\
12.3 \\
71.7\end{array}$ \\
\hline $\begin{array}{l}\text { Parity }(\mathrm{n}=243) \\
\quad 1 \\
2 \\
3 \\
>3\end{array}$ & $\begin{array}{r}100 \\
78 \\
36 \\
29\end{array}$ & $\begin{array}{l}41.2 \\
32.1 \\
14.8 \\
12.5\end{array}$ \\
\hline $\begin{array}{l}\text { Blood group } \\
\mathrm{A}+ \\
\mathrm{B}+ \\
\mathrm{AB}+ \\
\mathrm{O}+ \\
\mathrm{B}- \\
\mathrm{O}- \\
\text { Unknown }\end{array}$ & $\begin{array}{r}54 \\
58 \\
19 \\
108 \\
2 \\
1 \\
7\end{array}$ & $\begin{array}{c}21.6 \\
23.3 \\
7.6 \\
43.4 \\
0.8 \\
0.4 \\
2.8\end{array}$ \\
\hline $\begin{array}{l}\text { Occupation } \\
\text { Trained } \\
\text { Untrained } \\
\text { Professional } \\
\text { Unemployed }\end{array}$ & $\begin{array}{r}2 \\
7 \\
29 \\
211\end{array}$ & $\begin{array}{r}0.8 \\
2.8 \\
11.6 \\
84.7\end{array}$ \\
\hline Previous history of abortion & 40 & 16.1 \\
\hline Previous history of still birth & 6 & 2.4 \\
\hline $\begin{array}{l}\text { Immunisation } \\
\text { Tetanus not taken } \\
\text { Rubella not taken }\end{array}$ & $\begin{array}{r}8 \\
15\end{array}$ & $\begin{array}{l}3.2 \\
6.0\end{array}$ \\
\hline $\begin{array}{l}\text { Given birth ever to a baby } \\
\text { with congenital anomaly }\end{array}$ & None & None \\
\hline Maternal alcoholism & None & None \\
\hline Maternal smoking & None & None \\
\hline $\begin{array}{l}\text { History of chronic diseases } \\
\text { Diabetes } \\
\text { Hypertension } \\
\text { Asthma }\end{array}$ & $\begin{array}{r}6 \\
10 \\
6 \\
\end{array}$ & $\begin{array}{l}2.4 \\
4.0 \\
2.4 \\
\end{array}$ \\
\hline
\end{tabular}

*Significantly higher prevalence of $\mathrm{CM}$ in babies with mothers $>30$ year of age $(p=0.001)$

Birth weight of babies with $\mathrm{CM}$ is shown in table 4. Of the babies $23.9 \%$ were of low birth weight $(<2.5$ $\mathrm{kg}$ ). Characteristics of the fathers are presented in the table 5. Family history of CM was present in 9 (3.6\%). A significantly higher proportion of fathers were aged $>30$ years $(p=0.001)$.
Table 4. Association with the birth weight

\begin{tabular}{lcc}
\hline \multicolumn{1}{c}{ Birth weight $(\mathrm{kg})$} & Number & Percentage \\
\hline$<2$ & 30 & 12.1 \\
$2.1-2.4$ & 29 & 11.7 \\
$>2.5$ & 189 & 76.2 \\
\hline
\end{tabular}

Table 5. Characteristics of the father

\begin{tabular}{lcc}
\hline Characteristics & Number & Percentage (\%) \\
\hline Age (years) & 3 & 1.2 \\
$<20$ & 96 & 38.5 \\
$21-30$ & 150 & $60.0^{*}$ \\
$>30$ & & \\
Family history & 9 & 3.6 \\
of CM & 112 & 44.9 \\
Alcohol dependent & 89 & 35.7 \\
Smoking & \\
\hline
\end{tabular}

*Significantly higher prevalence of $\mathrm{CM}$ in babies with fathers $>30$ year of age $(p=0.001)$.

\section{Discussion}

The overall prevalence of CM in live new born babies was $4.3 \%$. The prevalence of congenital anomalies at birth in developed countries is reported to be between 3-5\% [15]. A study from India in 2010 reported a prevalence of $3.6 \%$ [16]. Prevalence in Japan was $1.1 \%$ and in Taiwan $4.3 \%[8]$.

There are only a few Sri Lankan studies of CM. The first in 1982 reported that the male: female ratio for central nervous system malformations was 2:1 [17]. A study at General Hospital Anuradhapura in North-Central Province of Sri Lanka in 2007 examined 9105 newborn babies for five selected congenital anomalies [18]. The prevalence rates per 10,000 live births were 31.8 for talipes-equinovarus, 26.3 for congenital dislocation of hip, 21.9 for cleft lip/cleft palate, 20.8 for Down's syndrome and 13.2 for neural tube defect.

In the present study highest frequency of $\mathrm{CM}$ were in the musculoskeletal system (31.2\%). A study from Iran also reported that the highest frequency of $\mathrm{CM}$ $(33 \%)$ was of the musculoskeletal system [14]. However, several studies carried out in India have reported that the commonest CM was in the central nervous system (44\%) [15]. Similar sex ratios to our study have been reported from India [19].

Mothers age was more than 35 years in $19.6 \%$ of babies with CM. Encouraging parents to complete the family before 35 years of age may be important in reducing the risk of $\mathrm{CM}$. About $84 \%$ of babies with $\mathrm{CM}$ were born at full term, $16 \%$ were preterm. The gestational age of all babies with $\mathrm{CM}$ was more than 29 weeks. Of the babies with CM $41 \%$ were first-borne. About $16.1 \%$ 
of the mothers had a history of abortion and $2.4 \%$ had a previous history of stillbirths. However, none had an elder child with CM. Fetal exposure to alcohol and smoke are well known causes of congenital anomalies. However, none of the mothers had consumed alcohol or smoked. Majority $(61.9 \%)$ of mothers had not consumed folic acid supplement before conceiving. This needs to be addressed as intrauterine folic acid deficiency is a known predisposing factor for CM. About $4.4 \%$ of babies were from consanguineous marriages. Majority of the mothers were unemployed and none of the employed mothers were exposed to occupational hazards.

\section{Limitations of the study}

This study was conducted in a referral centre with specialised maternal and neonatal care. Therefore the number of mothers and babies with complications could be more than that in the community. Hence the rate of occurrence of malformations among babies also could be more than that in the general population.

\section{Acknowledgements}

The authors thank the medical and nursing staff of the labour rooms, maternal wards and the premature baby unit of the Teaching Hospital, Mahamodara, Sri Lanka for their cooperation.

\section{References}

1. Patel PK. Profile of major congenital anomalies in the Dhahira region, Oman. Annals of Saudi Medicine 2007; 27: 106-11.

2. Ritz B. Air-pollution and congenital anomalies. Occupational and Environmental Medicine 2009; November 2.

3. Asindi AA, Ibia EO, Udo JJ. Mortality pattern in Nigerian children in the 1980s. Journal of Tropical Medicine and Hygiene 1991; 94: 152-5.

4. Behrnan RE. The field of pediatrics. In: Nelson WE, Behrman RE and Kliegman RM, eds. Nelson Textbook of Pediatrics 14th ed. Philadelphia: WB Saunders, 1992.

5. Forfar JO. Demography, vital statistics, and the pattern of disease in childhood. In: Campell AGM and McIntosh I, eds. Forfar and Arniel Textbook of Pediatrics. 4th ed. London: Churchill Livingstone; 1992: 1-17.

6. Turnpenny P, Ellard S.Emery's Elements of Medical Genetics. 12th ed. Elsevier Churchill Livingstone, Edinburg, UK, 2005.
7. Blomberg M, Selbing A, Kallen B. Congenital malformations in the southeast of Sweden - a registry study with validation. Acta Paediatrica 2000; 89: 1238-43.

8. Tomatir AG, Demirhan H, Sorkun HC, Koksal A, Ozerdem F, Cilengir N. Major congenital anomalies: a five-year retrospective regional study in Turkey. Genetic and Molecular Research 2009; 8: 19-27.

9. Dolk H, Loane MA, Abramsky L, de WH, Garne E. Birth prevalence of congenital heart disease. Epidemiology 2010; 21: $275-7$.

10. Temtamy SA, Meguid NA, Ismail SI, Ramzy MI. A new multiple congenital anomaly, mental retardation syndrome with preaxial brachydactyly, hyperphalangism, deafness and orodental anomalies. Clinical Dysmorphology 1998; 7: 249-55.

11. Hudgins L, Cassidy SB. Congenital anomaly. Martin RJ, Fanaroff AA, Walsh MC. Fanaroff. Neonatal-Perinatal Medicine Diseases of the Fetus and Infant, 8th edition, Elisvier, Philadelphia 2006; 561-81.

12. Harris J, James L. State-by-state cost of birth defects 1992. Teratology 1997; 56: 11-16.

13. Botto LD, Lynberg MC, Erickson JD.Congenital heart defects, maternal febrile illness, and multivitamin use: a population-based study. Epidemiology 2001; 12: 484-90.

14. Sedighah Akhavan Karbasi, Motaharah Golestan, Raziah Fallah, Fahimehsadat Mirnaseri, Kazem Barkhordari, Mahdokht Sadr Bafghee. Prevalence of Congenital Malformations. Acta Medica Iranica 2009; 47: 149-53.

15. Padma S, Ramakrishna D, Jijiya BP, Ramana PV. Pattern of distribution of congenital anomalies in stillborn: a hospital based prospective study. International Journal of Pharma and Bio Sciences 2011; 2: 605-7.

16. Bower CL, Lester-Smith D, Elliot EJ. Congenital anomalies why bother? Medical Journal of Australia 2010; 192: 3001.

17. Corea SMX. Epidemiology of congenital malformations in Sri Lanka. [Thesis for MD (Community Medicine)] 1982. Post Graduate Institute of Medicine, University of Colombo, Sri Lanka.

18. Alwis ACD, Silva KNS, Bandara WDMSD, Gamage TGPM. Prevalence of talipe sequinovarus, congenital dislocation of the hip, cleft lip/cleft palate, Down syndrome and neural tube defects among live newborns in Anuradhapura. Sri Lanka Journal of Child Health 2007; 36: $130-2$.

19. Bhat BV,Babu L. Congenital anomalies at birth - a prospective study in South India. Indian Journal of Pediatrics 1998; 65: 873-81. 